\title{
THE EFFECT OF BOARD OF DIRECTOR, AUDIT COMMITTEE, INSTITUTIONAL OWNERSHIP TO FIRM VALUE, WITH FIRM SIZE, FINANCIAL LEVERAGE, AND INDUSTRIAL SECTOR AS CONTROL VARIABLES (STUDY ON LISTED COMPANIES IN INDONESIAN STOCK EXCHANGE PERIOD 2011-2015)
}

\author{
Almira Santi Samasta1, Harjum Muharam², A. Mulyo Haryanto³ \\ ${ }^{1}$ Master of Management, Faculty of Economics and Business, Diponegoro University \\ ${ }^{2}$ Master of Management, Faculty of Economics and Business, Diponegoro University \\ ${ }^{3}$ Master of Management, Faculty of Economics and Business, Diponegoro University
}

\begin{abstract}
This study aims to examine the effect of corporate governance's mechanism to firm value which is proxied by Tobin's $Q$. This mechanism is divided into two, internal mechanism which is proxied by board of director and audit committee and external mechanism which is proxied by institutional ownership. This study is using control variables such as firm size, financial leverage and industrial sector.

Sample used in this study are 40 companies which incorporated in several industrial sector in Indonesia which are listed in Indonesia Stock Exchange during 2011-2015. Hypothesis testing in this study is using multiple regression analysis.

The result of this study shows that board of director has positive but insignificant effect to firm value in Indonesia, audit committee has positive and significant effect to firm value in Indonesia and institutional ownership has negative but insignificant effect to firm value in Indonesia. The control variables used in this study provide mixed results, where firm size has negative and insignificant effect to firm value, financial leverage has positive and significant effect to firm value and the whole industrial sector in Indonesia has no effect to firm value. From simultaneous test, this study shows that simultaneously independent variables significantly affect to firm value.
\end{abstract}

Key Words: Internal Mechanism, External Mechanism, Firm Value, Tobin's Q, Board Of Director, Audit Committee, Institutional Ownership, Firm Size, Financial Leverage, Industrial Sector, Corporate Governance.

\section{INTRODUCTION}

Implementation of corporate governance has been done by many companies because it is considered as an obligation for every company to run the business in accordance with applicable rules. Corporate governance itself can be interpreted as a mechanism that regulates the interaction of related parties within the company, where conflicts of interest can be minimized within the company, which impact on the value of the company. The mechanisms that can be used to support corporate governance are to have a board of directors and an audit committee as an internal corporate governance mechanism and institutional ownership as an external corporate governance mechanism. Based on existing data, the value of firms in Indonesia shows a downward trend during 2011 to 2015. This situation does not relevant to an increase in the number of boards of 
directors, audit committees and institutional ownership occurring in 2011 to 2015 . There are differences in the result of research conducted by some researchers on the influence of boards of directors, audit committees and institutional ownership to firm value.

The main motivation for this study was to examine the effectiveness of the corporate governance practice in Indonesia by examining the effect between corporate governance mechanisms and firm value. This study presents empirical evidence which differs from earlier regional studies, such as, Nuryanah and Islam (2011), because rather than examining the narrow issue of corporate governance, this study examine the broader mechanisms so that a whole implication could be drawn. For this purpose, this study investigated Indonesian publicly listed companies on Indonesia Stock Exchange (IDX).

The results of the effect between corporate governance mechanisms and firm value show that audit committee is an important attribute that can effect a firm's value. Similarly, the control variable, financial leverage, also impact firm value. This study failed to detect any effect between board of director and institutional ownership to firm value. The result of other control variables show that firm size and industrial sector does not affect the firm value.

The structure of this paper is as follows. The next section reviews the literature relating to corporate governance and firm value, and then build for hypotheses for the study. Section 3 discusses the research methodology and econometrics modelling of the study. Section 4 shows the details of the results and then section 5 discusses the implications of the study. The final chapter is the conclusion.

\section{LITERATURE REVIEW}

The value of the firm can be expressed as the selling price of the company approved by the prospective buyer, when the value of the company is higher so the prosperity of the owner of the company gets bigger. By maximizing the value of the company, it can be interpreted to maximize the prosperity of the company owner. Brigham and Houston (2007) explained that the main goal of management is to maximize the prosperity of shareholders by maximizing the company's stock price. Van Horne and Wachowicz (2008) stated that the prosperity earned by shareholders is represented by the market price of the company's stock, where the stock market price of the company is the valuation of all market participants as the value of the company. Ahmad and Jusoh (2014) say market performance measurement is used as performance indicator based on two reasons that is not influenced by certain reporting of company and management manipulation and use of stock price measurement more consistent with an important principle in agency theory where manager should maximize market value of company. There are several measurements of firm value based on the market value of the firm (market value). The measurement of corporate value that has been widely used in various studies that is Tobin's Q, formulating the value of the asset market compared with the expenditure of money for asset replacement (Sukamulja, 2004). The best information presentation can be made by Tobin's $Q$ because this ratio is able to provide an explanation of the events in the company (Sukamulja, 2004). Ahmad and Jusoh (2014) stating that Tobin's Q has been widely used by academics, researchers and practitioners and claimed to be the best market measurement tool, which can be used in the use of Tobin's $Q$ as a measure of corporate value.

Corporate governance can be summed up as a mechanism on the relationship between principals and agents in maximizing corporate value. The alignment of management and principal interests with 
the goal of reducing the agency conflict is the goal of corporate governance mechanisms (Dharmastuti, 2013; Hill and Jones, 2004 in Afza and Nazir, 2014). Mechanisms that run well so as to reduce agency problems and is expected to increase the company's value can be achieved when adjusted to the principles of corporate governance. The fact that good corporate governance can increase corporate value, Iskander and Chamlou (2000) in Nuryanah and Islam (2011) argue that the success of corporate governance practices that lead to increased corporate value is inseparable from both internal and external factors. Both of these factors can influence how corporate governance is applied in the company, both in terms of the company's internal running of the company and how the external side of the company relates to the company.

Regardless of the particular definitions that are often used, the mechanism appears to be two sides: internal and external mechanisms of the company (Gillan, 2006). Organizational sustainability in accordance with the rules governed by the leadership becomes the focus of internal mechanisms while the organization's relationship with outsiders takes place in harmony without neglecting the organization's objectives into the emphasis of external mechanisms (Wibowo, 2010). The main concern of internal mechanisms is the board of directors overseeing the operations and management processes, while external mechanisms include ownership structures, protection of minority shareholders and legal infrastructure (Abbasi, et.al., 2012).

The agency relationship within the company can be attributed to the implementation of corporate governance within the company. Principals give authority to others called agents, to perform actions based on principal interests can be defined as agency relationships (Jensen and Meckling, 1976).
Resources dependence theory explains how organizations reduce dependence and uncertainty about the environment. This theory describes the company as an open system that relies on resources in the external environment. Previous research on the role of the council in relation to resources dependence theory Hillman and Dalziel (2003) in Hillman et al. (2009) suggests the function of councils as: (a) supervision from agency theory perspective and (b) provision of resources from the perspective of resources dependence theory. The provision of resources here can be advice or direction, relationships with other parties, access to resources needed to run the company.

The underlying assumption that information received by each party is not the same (information asymmetry) becomes the basis for signal theory. In this case, information gained from the existence of corporate governance mechanism in order to increase the value of the company. The existence of the board of directors, audit committee and institutional ownership is expected to perform their respective roles in minimizing agency conflict that occurs in the company that will affect the company's value. More attention to this corporate governance is the size or number of boards of directors, audit committees and institutional ownership of corporate value. The existence of a larger board of directors, audit committee and institutional ownership is expected to perform its functions optimally in increasing the value of the company.

The board of directors is usually seen as a key mechanism in corporate governance and the primary means for shareholders to oversee management activities (John and Senbet, 1998 in Al-Matar, et al., 2014). Coles, et.al (2008) suggests that better monitoring that improves the company's performance is derived from larger board sizes, so that there is a positive influence between the size of the board of directors and the firm value. 
For example, large and diverse boards of directors may improve board performance in terms of knowledge and expertise (Nuryanah and Islam, 2011). Based on Fauzi and Locke (2012), it can be seen from the perspective of agency theory that large boards tend to be alert to agency problems because of the larger number that will oversee management action; viewed from the perspective of resource dependence theory, it can be explained that greater opportunities for relationships and access to resources can be obtained through larger boards of directors. In accordance with the research of El-Faitouri (2014) found results that the size of the board of directors positively affect the value of the company on 634 companies listed on the London Stock Exchange.

\section{H1: The board of directors has a positive effect Firm Value}

The audit committee is defined as an individual selected by the board of commissioners who has duties to assist in the overall oversight process including corporate governance, financial reporting and corporate oversight. Several studies have reported that the audit committee measure is an influential factor in the effectiveness of a firm's work (Pincus et al in Afza and Nasir, 2014). By having the ideal amount of audit committee within a company, it is expected to improve the quality of the information flow between shareholders and managers that will reduce agency problems. A minimum of three members of the audit committee have been proposed by a number of corporate governance reports (CMA, 2006 in AlMatari, et.al., 2012). Based on the premise of resource dependence theory, the company's performance will be better as the size of the audit committee (Al-Matar, et.al., 2014) increases. Can be explained as the number of audit committees increases then the market will see that more qualified resources and experts to solve accounting and financial problems are owned by the audit committee
(Afza and Nazir, 2014). Similar research conducted by Gill and Obradovich (2012); Afza and Nasir (2014); Al Matar, et.al (2014) who found a positive influence between audit committee and firm value.

\section{H2: The Audit Committee has a positive effect on Corporate Value}

Susanti and Mildawati (2014) stated that the existence of institutional ownership other than in supervising the activities of the company effectively, can also supervise the management in decision making because they participate so that not affected management action. In addition, institutional investors are considered to have the power to influence board decisions, reduce oversight costs, engage in active ownership so that their presence affects the company's performance (Shleifer and Vishny, 1997 in Alfaraih, et.al, 2012). According to Thanatawee (2014), along with the high agency problem, institutional investors act more actively in supervision of management performance which will increase the company's value. Viewed from the perspective of agency theory, institutional ownership that is a big shareholder tends to be alert to agency problems, because with large investments they will more closely supervise the actions of management. Supervision by institutions is deemed to be able to replace the emerging agency costs so that agency costs can be minimized which will impact on increasing company value. Managers' opportunistic behavior can be minimized by increasing institutional ownership that impacts on agency costs and increased company value (Wahyudi and Pawestri, 2006 in Susanti and Mildawati, 2014). The study by Abbasi, et al. (2012); Thanatawee (2014); Ahmad and Jusoh (2014) found a positive influence between institutional ownership and firm value

\section{$\mathrm{H}_{3}$ : Institutional ownership positively affects Firm Value}




\section{METHOD}

The data used in this research are secondary data and the sample used are companies listed in Indonesia Stock Exchange period 2011-2015. Based on predetermined criteria, the amount used is 40 companies and the research period for 5 years so that the amount of data observed in this research is 200 companies.
The dependent variable used in this research is Tobin's Q. The independent variables used in this study are board of directors, audit committee and institutional ownership. The last is the use of control variables such as firm size, financial leverage and industrial sectors that aim to control the firm's characteristics that affect the value of the company (Sari and Usman, 2014).

Table 1

\section{Operational Definition}

\begin{tabular}{|c|c|}
\hline Variables & Measurement \\
\hline \multicolumn{2}{|l|}{ Firm Value } \\
\hline \multicolumn{2}{|r|}{ Tobin's $Q=\frac{\text { market value of equity+book value of debt }}{\text { book value of total asset }}$} \\
\hline Board of Director & Total numbers of board of directors within company \\
\hline Audit Committee & Total numbers of audit committee within company \\
\hline \multicolumn{2}{|l|}{ Institutional } \\
\hline \multicolumn{2}{|l|}{ Firm Size } \\
\hline & $F S=$ Ln Total Asset \\
\hline \multicolumn{2}{|r|}{$F L=\frac{\text { Total liabilities }}{\text { Total Assets }}$} \\
\hline \multirow[t]{6}{*}{ Industrial Sector } & $\begin{array}{l}\text { 1. Agriculture, assigned value } 1 \text { for agriculture and } 0 \text { for } \\
\text { other industrial sector }\end{array}$ \\
\hline & $\begin{array}{l}\text { 2. Mining, assigned value } 1 \text { for mining and } 0 \text { for other } \\
\text { industrial sector }\end{array}$ \\
\hline & $\begin{array}{l}\text { 3. Manufacture, assigned value } 1 \text { for manufacture and } 0 \\
\text { for other industrial sector }\end{array}$ \\
\hline & $\begin{array}{l}\text { 4. Property, Real Estate and Building Construction, } \\
\text { assigned value } 1 \text { for Property, Real Estate and Building } \\
\text { Construction and } 0 \text { for other industrial sector }\end{array}$ \\
\hline & $\begin{array}{l}\text { 5. Infrastructure, Utilities and Transportation, assigned } 1 \\
\text { for Infrastructure, Utilities and Transportation and } 0 \text { for } \\
\text { other industrial sector }\end{array}$ \\
\hline & $\begin{array}{l}\text { 6. Trade and Services, assigned value } 1 \text { for Trade and } \\
\text { Services and } 0 \text { for other industrial sector }\end{array}$ \\
\hline
\end{tabular}

Data technique used in this research is multiple regression analysis by using Least Square Dummy Variable. The research model is required to fulfill the classical assumptions consisting of normality test, multicollinearity test, heteroskedaticity test and autocorrelation test. This study uses two regression equations:

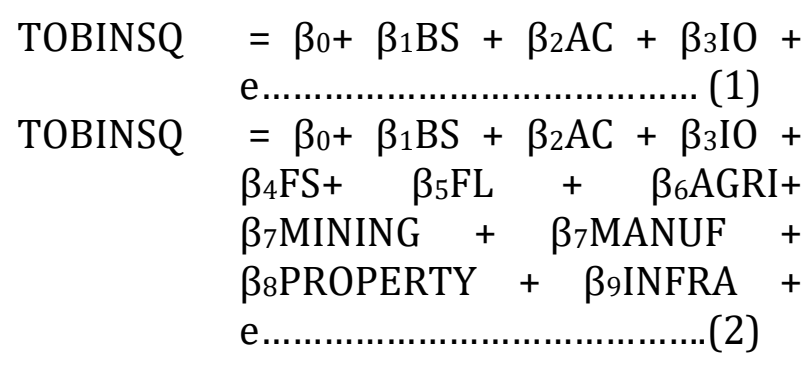


Variables:

$\begin{array}{ll}\text { TOBINSQ } & =\text { Firm Value } \\ \text { BS } & =\text { Board of Director } \\ \text { AC } & =\text { Audit Committee } \\ \text { IO } & =\text { Institutional } \\ & \text { Ownership } \\ \text { FS } & =\text { Firm Size } \\ \text { FL } & =\text { Financial Leverage } \\ \text { AGRI } & =\text { Agriculture } \\ \text { MINING } & =\text { Mining } \\ \text { D3 } & =\text { Manufacture } \\ \text { D4 } & =\text { Property } \\ \text { D5 } & =\text { Infrastructure }\end{array}$

\section{RESULT AND DISCUSSION}

Based on the test results, the two equations have met the classical assumption test so that the test can be done by using multiple regression analysis. There is adding lag on dependent variable as a healing of autocorrelation problem. Test results from both models can be seen in table 2 below:

Table 2

Test Results

\begin{tabular}{|c|c|c|c|c|}
\hline \multirow{2}{*}{ Variabel } & \multicolumn{2}{|c|}{ Model 1} & \multicolumn{2}{|c|}{ Model 2} \\
\hline & B & Sig. & $\boldsymbol{\beta}$ & Sig. \\
\hline BS & 0,002 & 0,865 & 0,016 & 0,314 \\
\hline AC & 0,142 & $0,023^{* *}$ & 0,136 & $0,043^{* *}$ \\
\hline IO & $-0,000$ & 0,790 & $-0,000$ & 0,568 \\
\hline FS & - & - & $-0,034$ & 0,092 \\
\hline FL & - & - & 0,003 & $0,037^{* *}$ \\
\hline AGRI & - & - & $-0,024$ & 0,834 \\
\hline MINING & - & - & $-0,051$ & 0,630 \\
\hline MANUF & - & - & 0,010 & 0,895 \\
\hline PROPERTY & - & - & $-0,038$ & 0,677 \\
\hline INFRA & - & - & $-0,033$ & 0,740 \\
\hline TOBINSQ(-1) & 0,450 & 0,000 & 0,422 & $0,000 * * *$ \\
\hline $\mathbf{C}$ & 0,313 & 0,135 & 1,162 & 0,033 \\
\hline Adjusted $R$-squared & \multicolumn{2}{|c|}{0,234} & \multicolumn{2}{|c|}{0,239} \\
\hline F-stat & \multicolumn{2}{|c|}{16,149} & \multicolumn{2}{|c|}{6,676} \\
\hline$p$-value & \multicolumn{2}{|c|}{0,000} & \multicolumn{2}{|c|}{0,000} \\
\hline Observation & \multicolumn{2}{|c|}{199} & \multicolumn{2}{|c|}{199} \\
\hline
\end{tabular}

Dependent: TobinsQ

$*, * *, * * *$ shows significamtly ar 10\%, 5\% dan $1 \%$

\section{Discussion}

\section{$H_{1}$ : The Board of Directors has a positive effect on Corporate Value}

The test result on both models shows the value of positive regression coefficient but with significance value> 0,05 meaning that there is positive but not significant influence between board of directors with company value. This can be explained by the small variation in the size of the board of directors used as the proxy of the board of directors, so as not to give a significant effect on the value of the company.

The results of this study are in line with research conducted by Alfaraih et.al (2012), Kritika and Choudary (2015), and 
Sharma (2016) which found no significant influence between the board of directors and firm value.

\section{H2: The Audit Committee has a positive effect on Corporate Value}

Test results on both models show the value of positive regression coefficient with significance value $<0.05$ which means that there is a positive and significant influence between the audit committee on firm value. This can be explained because the existence of audit committees is necessary given the still growing Indonesian capital market and weak external corporate governance mechanisms, the audit committee as an independent party within the company is considered more important than the number of boards of directors by market members.

The results of this study are in line with research conducted by Gill and Obradovich (2012), Fauzi and Locke (2012) and Afza and Nazir (2014) which found positive and significant results between audit committees and firm values.

\section{H3: Institutional ownership positively affects Corporate Value}

The test result on both models shows the value of negative regression coefficient but with significance value $>0,05$ meaning that there is negative but not significant influence between institutional ownership and firm value. This can be explained because most of the institutional ownership of the company is concentrated in one or more companies, so that the function of supervision on the performance of management is not optimal, there is a tendency to experience a conflict of interest problems.

The results of this study are in line with research conducted by Katan and Nor (2015) sera Kaur (2016) which found no significant impact between institutional ownership and firm value.

Based on the results of the analysis, firm size control variables show the result of a negative but not significant influence between firm size and firm value. This may indicate that firm size is not one of the factors that affect the value of the company. The size of the company is not a guarantee that the resources used from asset ownership can be used to increase the value of the company and become the level of investor confidence to invest in the company. Financial leverage shows the result that there is a significant positive influence between financial leverage with firm value. This indicates that the financial leverage becomes a factor that affects the value of the company. It can be explained that the use of larger debt indicates the company has a better picture of investment in the future and the relationship with high debt with the interest tax shield, so as to respond positively by the market. The industrial sector control variables in Indonesia show the result of no effect on all industrial sectors in Indonesia, with negative direction tendencies. This means that the industrial sector in Indonesia does not have differences in industrial characteristics that affect the value of the company.

Based on the results of the analysis, there is a lag of the dependent variable Tobin's $Q(-1)$ as the remedy step of the autocorrelation problem in the research model. This means that the value of the company is currently influenced by the value of the company in the past with a positive and significant direction, so that if there is a change in the value of the company in the past it will increase the value of the company now.

The equations obtained from the test results are:

$$
\begin{gathered}
\text { TOBINSQ = 1,162 + 0,016BS + 0,136AC } \\
- \text { 0,000IO - 0,003FS + 0,003FL } \\
- \text { 0,002AGRI - 0,051MINING + } \\
\text { 0,010MANUF - 0,038PROPERTY } \\
\text { - 0,033INFRA + 0,422TOBINSQ(-1) }
\end{gathered}
$$




\section{CONCLUSIONS, LIMITATION AND SUGGESTION \\ Conclusion}

This study examines the effect of board of directors, audit committee and institutional ownership on firm value with firm size, debt and industrial sector as control variables. From the research result, it can be concluded as follows:

1. Board of directors have positive but not significant effect on company value. This result can be explained because the variation in the size of the board of directors used as a proxy is very small.

2. Audit Committee has positive and significant impact on company value. This can be explained because the existence of audit committees is necessary given the still growing Indonesian capital market and weak external corporate governance mechanisms, the audit committee as an independent party within the company is considered more important than the number of boards of directors by market members.

3. Institutional ownership is negative but not significant to firm value. This can be explained because most of the institutional ownership of the company is concentrated in one or more companies, so that the function of supervision on the performance of management is not optimal, there is a tendency to experience a conflict of interest problems.

4. The control variables used in the study provide mixed results, where the size of the company has a negative but not significant effect on the value of the company, the financial leverage positively affects the value of the company and the industrial sector has no effect on the value of the company.

\section{Limitations}

Limitations in this study are adjusted result $\mathrm{R}^{2} \quad 0.239$ indicating that the independent variables and control variables used only able to explain the effect on the company value of $23.9 \%$ and $76.1 \%$ explained by other independent variables outside the model.

\section{Suggestion}

From the limitations of the research, the suggestion that can be given for the future research is to add other variables that are considered to have an effect on the value of the company such as the characteristics of the board of directors, the characteristics of the board of commissioners, the characteristics of the audit committee, other forms of stock ownership, the growth rate of the company and so on.

\section{REFERENCES}

Abbasi, M., Kalantari, E., dan Abbasi, H. (2012). "Impact of Corporate Governance Mechanisms on Firm Value Evidence from the Food Industry of Iran". Journal of Basic and Applied Scientific Research. 2(5). Pp. 4712-4721

Afza, T. dan Nazir, M.S. (2014). "Audit Quality and Firm Value: A Case of Pakistan". Research Journal of Applied Science, Engineering and Technology. 7(9). pp. 1803-1810

Ahmad, A.C. dan Jusoh, M.A. (2014). "Institutional Ownership and Market Based Performance Indicators: Utilizing Generalized Least Square Estimation". Procedia - Social and Behavioral Sciences. Pp 477-485.

Alfaraih, M., Alanezi, F., dan Almujamed, H. (2012). "The Influence of Institutional and Government Ownership on Firm Performance: Evidence from Kuwait. International Business Research". 5(10). Pp. 192-200. 
Al-Matari, E.M., Al Swidi, A.K., dan Fadzil, F.H.B. (2014). "The Effect of Board of Directors Characteristics, Audit Committee Characteristics and Executive Committee Characteristics on Firm Performance in Oman: An Empirical Study". Asian Social Science. 10(11). pp. 149-171

Al-Matari, Y.A., Al Swidi, A.K., Fadzil, F.H.B., dan Al-Matari, E.M. (2012). "Board of Directors, Audit Committee Characteristics and Performance of Saudi Arabia Listed Companies”. International Review of Management and Marketing. 2(4). pp. 241-251.

Brigham, E.F. dan Houston, J.F. (2006). Fundamentals of Financial Management. $11^{\text {th }}$ Edition. Cengage Learning.

Coles, J.L., Daniel, N.D. dan Naveen, L. (2008). “Boards: Does One Size Fit All?”. Journal of Financial Economics. 87. pp. 329-356.

Dharmastuti, C.F. (2013). "Analisi Pengaruh Mekanisme Internal dan External Corporate Governance Terhadap Profitabilitas dan Kebijakan Deviden Perusahaan (Studi Empiris Pada Perusahaan Go Publik di Pasar Modaal Indonesia)". Jurnal Organisasi dan Manajemen. 9(1). Pp : 21-30

El-Faitouri, R. (2014). “Board of Directors and Tobin's Q: Evidence from U.K. Firms”. Journal of Finance and Accounting. 2(4). Pp. 82-99.

Fauzi, F. dan Locke, S. (2012). "Board Structure, Ownership Structure and Firm Performance: A Study of New Zealand Listed Firms". Asian Academy of Management Journal of Accounting and Finance. 8(2). Pp. 43-67

Gill, A. dan Obradovich, J.D. (2012). "The Impact of Corporate Governance and Financial Leverage on The Value of American Firms". International Research Journal of Finance and Economics. Issue 91. pp. 1-14

Gillan, S.L. (2006). "Recent Development in Corporate Governance: An Overview”. Journal of Corporate Finance. 12. Pp: 381-402.

Hillman, A.J., Withers, M.C. and Collins, B.J. (2009). "Resources Dependence Theory: A Review". Journal of Management. 35(6). Pp: 1404-1427.

Jensen, M.C. dan Meckling, W.H. (1976). "Theory of the Firm: Managerial Behaviour, Agency Cost and Ownership Structure". Journal of Financial Economics. 3(4). pp. 305-360.

Katan, H. dan Nor. F.M. (2014). "Institutional Ownership Heterogeneity and Firm Performance: Evidence from Malaysia". International Journal of Economics and Finance. 7(12). Pp: 176-188.

Kaur, G. (2016). "Effect of Board Size and Promoter Ownership on Firm Value: A Study of Indian Company". International Journal of Management and Commerce Innovations. 3(2). Pp.303-311

Kritika dan Choudary, V. (2015). "Impact of Board Size on Firm Performance: A Study of Selected BSE 500 Companies". Appejay Journal of Management and Technology. 10(1). Pp:34-40.

Nuryanah, S. dan Islam, S.M.N. (2011). “Corporate Governance and Performance: Evidence from Emerging Market”. Malaysian Accounting Review. 10(1). Pp. 17-42. 
Sharma, A.A.C. (2012). "Corporate Governance and Firm Performance in Developing Countries: Evidence from India". The International Journal of Business in Society. 16(22). Pp: 1-27.

Sukamulja, S. (2004). "Good Corporate Governnace di Sektor Keuangan: Dampak GCG Terhadap Kinerja Perusahaan”. Benefit. 8(1). Pp: 1-25.

Susanti, R. dan Mildawati, T. (2014). "Pengaruh Kepemilikan Manajemen, Kepemilikan Institusional dan Corporate Social Responsibility Terhadap Nilai Perusahaan". Jurnal Ilmu dan Riset Akuntansi. 3(1). Pp. 1-18.

Thanatawee, Y. (2014). "Institutional Ownership and Firm Value in Thailand". Asian Journal of Business and Accounting. 7(2). Pp. 1-22.

Van Horne, J.C. dan Wachowicz, J.M. (2008). Fundamentals of Financial Management. 13th ed. Pearson: England.

Wibowo, E. (2010). "Implementasi Good Corporate Governance di Indonesia". Jurnal Ekonomi dan Kewirausahaan. 10(2). Pp.129-138. 